\title{
Heart Failure Elevates Serum Levels of Cibenzoline in Arrhythmic Patients
}

\author{
Takeshi Kotake, BS; Mitsutaka Takada, PhD; Kazuo Komamura, MD*,**; \\ Shiro Kamakura, MD*; Kunio Miyatake, $\mathrm{MD}^{\dagger}$; \\ Masafumi Kitakaze, MD*; Hideki Morishita, BS
}

\begin{abstract}
Background Cibenzoline dosing is generally based on renal function, but serum concentrations might be greater than the expected therapeutic levels when standard oral dosing is used. Because heart failure might modify cibenzoline pharmacokinetics, the difference in cibenzoline pharmacokinetics between patients with and without heart failure was evaluated.

Methods and Results The study enrolled 368 patients (233 men, 135 women) that had been hospitalized and received cibenzoline therapy at the National Cardiovascular Center from January 2001 to May 2005. There were 89 patients with heart failure (51 men, 38 women) and 279 patients without heart failure (182 men, 97 women). They had therapeutic drug monitoring $\geq 3$ days after the beginning of treatment with cibenzoline. Brain natriuretic peptide (BNP) was measured in 81 patients (50 men, 31 women) concurrently with therapeutic drug monitoring of cibenzoline. The difference in serum cibenzoline concentration/(dose/weight) (C/D) values between patients with and without heart failure was analyzed using analysis of covariance (ANCOVA) with creatinine clearance (Ccr) serving as the covariate. The effects of dose/weight and the log-transformed BNP (log-BNP) values on serum cibenzoline concentrations were also assessed using ANCOVA. There were 135 and 361 measurements of serum cibenzoline concentration in patients with and without heart failure, respectively. Pearson's correlation coefficient analyses in the patients with and without heart failure revealed that the C/D values were significantly correlated with $\mathrm{Ccr}$ (with heart failure, $\mathrm{y}=-0.837 \mathrm{x}+169, \mathrm{r}=-0.211, \mathrm{p}=0.014$; without heart failure, $\mathrm{y}=-0.789 \mathrm{x}+$ $132, r=-0.393, p<0.001$ ), and the ANCOVA model indicated that $C / D$ values were significantly higher in patients with heart failure than without heart failure. The ANCOVA model also showed that dose/weight, Ccr and the log-BNP value were significant factors.

Conclusions The selection of a cibenzoline dose based only on renal function may increase the risk of toxicity in patients with heart failure. Cardiac function should be taken into account in cibenzoline dosing. The log-BNP may be a useful index for predicting serum cibenzoline concentrations. (Circ J 2006; 70: 588-592)
\end{abstract}

Key Words: Antiarrhythmic drug; Brain natriuretic peptide; Cibenzoline; Heart failure; Therapeutic drug monitoring

D rugs are generally used in accordance with approved dosing regimens, taking into account typical pharmacokinetic parameters of an individual patient that are predicted from patient-specific factors such as body size and renal function, ${ }^{1,2}$ For drugs that undergo renal excretion, a precise nomogram is required for patients with impaired renal function, 1,2 but plasma drug concentrations in patients with impaired renal function might be greater than therapeutic levels when a standard oral dose is used? It was reported that there was discrepancy for some drugs between the dose used in clinical practice and the dose recommended in the approved dosing regimen, 4 and there are some reports that the recommended dose occasionally led to an unexpected outcome $3,5,6$ Cibenzoline, a Vaughan Williams class-1a antiarrhythmic drug, is frequently used

(Received November 24, 2005; revised manuscript received February 6, 2006; accepted February 20, 2006)

Department of Pharmacy, *Division of Cardiology, **Department of Cardiovascular Dynamics, Research Institute, National Cardiovascular Center, Suita and Division of Cardiology, National Organization Osaka Minami Medical Center, Kawachinagano, Japan

Mailing address: Takeshi Kotake, BS, Department of Pharmacy, National Cardiovascular Center, 5-7-1 Fujishirodai, Suita 565-0873,

Japan. E-mail: kotaket@hsp.ncvc.go.jp for the treatment of ventricular and supraventricular arrhythmias and the improvement of left ventricular pressure gradient ${ }^{7-9}$ Pharmacokinetic studies conducted in healthy subjects have shown that cibenzoline is well absorbed in the digestive tract after oral dosing, and as much as $60 \%$ of the dose is excreted unchanged in the urine! ${ }^{10,11}$ The therapeutic and toxic effects of cibenzoline are well correlated with plasma concentrations of the parent drug, and an antiarrhythmic effect is observed between $200-400 \mathrm{ng} / \mathrm{ml} !^{12}$ Adverse effects such as proarrhythmia, hypotension and hypoglycemia have been observed at higher concentrations, ${ }^{13-15}$ and gastrointestinal disturbances, nervousness, tremulousness, dry mouth, and urinary retention are attributable to the anticholinergic properties of cibenzoline ${ }^{6}$ In patients receiving oral cibenzoline, the elimination half-life ranges from 8 to $22 \mathrm{~h}$ and appears to increase with age. In patients with renal impairment, total body clearance of cibenzoline decrease, together with a deterioration in renal function. Massarella et al reported that the pharmacokinetics of cibenzoline in patients with moderate chronic congestive heart failure do not differ from those in healthy subjects; ${ }^{17}$ however, that report was based on a small number of cases and did not include patients in severe stages of heart failure. The influence of chronic congestive heart fail- 
Table 1 Characteristics of the Study Patients With Heart Failure and Without Heart Failure

\begin{tabular}{lcc}
\hline \hline & Heart failure & Without heart failure \\
\hline Patients gender, number & Men 51, women 38 & Men 182, women 97 \\
NYHA $(\mathrm{I} / \mathrm{II} / \mathrm{III} / \mathrm{IV})$ & $23 / 43 / 19 / 4$ & 361 \\
Total measurements of serum cibenzoline concentration & 135 & $66.1 \pm 11.8(17-88)$ \\
Age $($ years $)$ & $64.7 \pm 12.1(36-98)$ & $58.0 \pm 11.5(29.0-90.0)$ \\
Weight $(\mathrm{kg})$ & $56.2 \pm 12.3(31.0-86.6)$ & $161 \pm 9.11(140-192)$ \\
Height $(\mathrm{cm})$ & $159 \pm 9.96(137-184)$ & $3.34 \pm 1.33(0.91-10.0)$ \\
Dosage/weight $(\mathrm{mg} / \mathrm{kg})^{*}$ & $3.00 \pm 1.27(0.69-8.16)$ & $189 \pm 72.9(50-550)$ \\
Dosage/day $(\mathrm{mg} / \text { day })^{* *}$ & $163 \pm 67.0(25-300)$ & $235 \pm 129(36-859)$ \\
Serum concentration $(\mathrm{ng} / \mathrm{ml}) * *$ & $316 \pm 244(28-1,839)$ & $77.2 \pm 52.2(16.8-600)$ \\
Serum concentration/ $($ dosage/weight $)(\mathrm{mg} / \mathrm{ml}) * *$ & $118.2 \pm 93.1(14.0-586)$ & \\
Hepatic and renal function test value & & $29.2 \pm 26.8(10-401)$ \\
AST $(\mathrm{U} / \mathrm{L})^{*}$ & $36.0 \pm 39.1(12-346)$ & $33.0 \pm 49.5(2-726)$ \\
ALT $(\mathrm{U} / \mathrm{L})$ & $33.8 \pm 38.7(3-286)$ & $19.6 \pm 9.69(5-74)$ \\
BUN $(\mathrm{mg} / \mathrm{ml})^{* *}$ & $22.6 \pm 10.0(9-71)$ & $0.93 \pm 0.64(0.30-8.60)$ \\
Scr $(\mathrm{mg} / \mathrm{ml})^{*}$ & $1.05 \pm 0.55(0.49-4.19)$ & $69.9 \pm 26.0(5.1-169)$ \\
Ccr $(\mathrm{ml} / \mathrm{min})^{* *}$ & $60.2 \pm 23.5(10.9-129)$ & \\
\hline
\end{tabular}

Data are mean \pm standard deviations (range). Student's t-test; ${ }^{*} p<0.05, * * p<0.01$.

NYHA, New York Heart Association; AST, aspartate aminotransferase; ALT, alanine aminotransferase; BUN, urea nitrogen; Scr, serum creatinine; $\mathrm{Ccr}$, creatinine clearance.

Table 2 Change to Characteristics of the Study Patients in Whom BNP was Measured

\begin{tabular}{lc}
\hline \hline & \\
\hline Patients gender, number & Value \\
Total measurements of serum cibenzoline concentration & Men 50, women 31 \\
Age $($ years $)$ & 94 \\
Weight $(\mathrm{kg})$ & $65.8 \pm 13.8(18-87)$ \\
Height $(\mathrm{cm})$ & $56.9 \pm 11.6(31.0-87.0)$ \\
Dosage/weight $(\mathrm{mg} / \mathrm{kg})$ & $159 \pm 9.72(140-177)$ \\
Dosage/day $(\mathrm{mg} /$ day $)$ & $3.27 \pm 1.25(0.92-7.55)$ \\
Serum concentration $(\mathrm{ng} / \mathrm{ml})$ & $179 \pm 62.6(75-300)$ \\
Serum concentration/ $($ dosage/weight $)(\mathrm{mg} / \mathrm{ml})$ & $283 \pm 206(30-1,457)$ \\
Hepatic and renal function test value & $94.9 \pm 71.3(14.0-378)$ \\
AST $(\mathrm{U} / \mathrm{L})$ & \\
ALT $(\mathrm{UIL})$ & $35.9 \pm 44.6(12-401)$ \\
BUN $(\mathrm{mg} / \mathrm{ml})$ & $41.5 \pm 81.5(9-726)$ \\
Scr $(\mathrm{mg} / \mathrm{ml})$ & $21.1 \pm 10.6(9-71)$ \\
Ccr $(\mathrm{ml} / \mathrm{imin})$ & $1.01 \pm 0.56(0.40-4.19)$ \\
BNP $(\mathrm{ng} / \mathrm{ml})$ & $61.9 \pm 22.9(11.5-166)$ \\
& $243 \pm 313(13.4-2,390)$
\end{tabular}

Data are mean \pm standard deviations (range).

$B N P$, brain natriuretic peptide. Other abbreviations see in Table 1.

ure on cibenzoline pharmacokinetics has not been clearly defined. Thus, in the present study, we evaluated the impact of heart failure on cibenzoline pharmacokinetics.

\section{Methods}

Subjects

Data were retrospectively collected from 368 patients (233 men, 135 women) who had been hospitalized at the National Cardiovascular Center from January 2001 to May 2005 and received therapeutic drug monitoring $\geq 3$ days after beginning treatment with cibenzoline. Patients were excluded from the study if hepatic and renal function was not measured and the time of collecting blood samples was uncertain. The trough levels of cibenzoline were determined and used for analysis. Characteristics of the study patients are presented in Table 1 . There were 89 patients with heart failure (51 men, 38 women) and 279 patients without heart failure (182 men, 97 women). The diagnosis of heart failure was based on a history of dyspnea and symptomatic exercise intolerance with signs of pulmonary congestion, peripheral edema, documentation of left ventricular enlarge- ment or dysfunction by physical examination, X-ray, echocardiography or radionuclide ventriculography. The functional severity of heart failure was classified according to the New York Heart Association (NYHA) class. There were $23,43,19$, and 4 patients with class I, II, III and IV, respectively. In the patients with heart failure, cibenzoline was used for treatment of atrial fibrillation (76 patients), atrial flutter (12 patients), premature atrial contraction (5 patients), supraventricular tachycardia (1 patient), ventricular tachycardia (10 patients), and hypertrophic obstructive cardiomyopathy (4 patients). In patients without heart failure, cibenzoline was used for treatment of atrial fibrillation (247 patients), atrial flutter (43 patients), premature atrial contraction (8 patients), supraventricular tachycardia (6 patients) and hypertrophic obstructive cardiomyopathy ( 1 patient). There were 81 patients (50 men, 31 women) in whom brain natriuretic peptide (BNP) was measured concurrently with therapeutic drug monitoring (Table 2). In these patients, 29 were diagnosed as having heart failure, 38 had a previous history of heart failure, and 14 were suspected of having heart failure. 


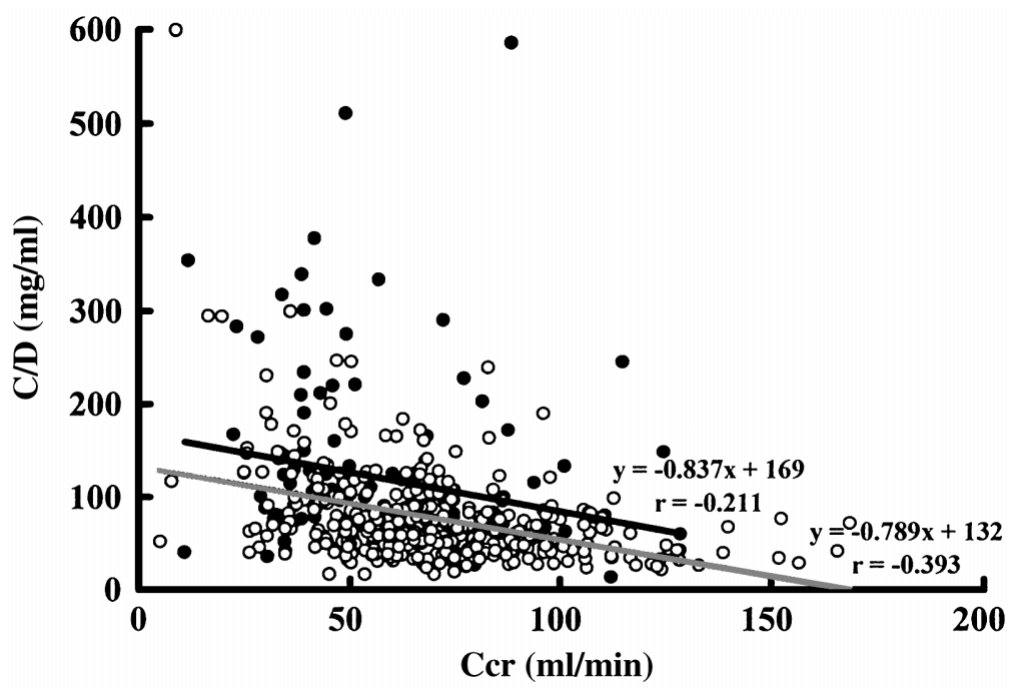

Fig 1. Differences in serum concentration/(dosage/ weight) $(\mathrm{C} / \mathrm{D})$ values between the patients with and without heart failure were analyzed using analysis of covariance with creatinine clearance (Ccr) serving as the covariate. These were significant differences in $\mathrm{C} / \mathrm{D}$ values of cibenzoline $(\mathrm{p}<0.001)$ between without heart failure $(\bigcirc$, halftone line) and with heart failure (, solid line) by analysis of covariance. Regression equations are as follows: C/D values of cibenzoline correlated with $\mathrm{Ccr}$ without heart failure, $\mathrm{y}=-0.789 \mathrm{x}+$ $132, \mathrm{r}=-0.393, \mathrm{p}<0.001$, with heart failure, $\mathrm{y}=$ $-0.837 \mathrm{x}+169, \mathrm{r}=-0.211, \mathrm{p}=0.014$.

Table 3 General Linear Model, Analysis of Covariance, Serum Concentration of Cibenzoline Outcome by Dose/Weight, Ccr and LogBNP Value

\begin{tabular}{lcrrrrc}
\hline \hline & Type III sum of squares & Df & Mean square & \multicolumn{1}{c}{$F$} & Sig. & Eta2 \\
\hline Corrected model & $1,176,235$ & 3 & 392,078 & 12.694 & 0.0000005 & 0.29733 \\
Intercept & 236 & 1 & 236 & 0.008 & 0.9306078 & 0.00008 \\
Dose $/$ weight $(\mathrm{mg} / \mathrm{kg})$ & 604,922 & 1 & 604,922 & 19.585 & 0.0000269 & 0.17872 \\
Ccr $(\mathrm{ml} /$ min) & 223,390 & 1 & 223,390 & 7.233 & 0.0085315 & 0.07438 \\
LogBNP value & 204,445 & 1 & 204,445 & 6.619 & 0.0117253 & 0.06851 \\
Error & $2,779,797$ & 90 & 30,887 & & & \\
Total & $11,462,906$ & 94 & & & & \\
Corrected total & $3,956,033$ & 93 & & & & \\
Multiple regression expression & Cp $=64.548 \cdot$ Dose/Weight-2.221 CCr $+102.436 \cdot$ LogBNP-10.389 & & \\
Regression coefficient & $R=0.545$ & & & & &
\end{tabular}

Results of the analysis of covariance model indicate that dose/weight $(p<0.001), C \mathrm{cr}(p=0.008)$ and LogBNP value $(p=0.012)$ are significant factors.

Df, degree of freedom; Sig., significance probability; Eta2, partialeta squared; Ccr, creatinine clearance; LogBNP, log-transformed brain natriuretic peptide.

\section{Data Collection}

Data on age, gender, weight, height, cibenzoline dosage, and laboratory data (aspartate aminotransferase (AST), alanine aminotransferase (ALT), blood urea nitrogen (BUN), serum creatinine (Scr), BNP) were collected from the patients' medical records. Creatinine clearance (Ccr) was calculated by the Cockcroft-Gault formula: $18 \mathrm{Ccr}=(140-$ age $) \times($ body weight $) \times 72^{-1} \times \mathrm{Scr}^{-1} \times(0.85$ if the patient is female).

Assay

Serum cibenzoline concentrations were measured at least 3 or more days after the start of administration using high-performance liquid chromatography as described by Hackman et al ${ }^{19}$ with some modifications. Blood samples for drug assay were collected in vacuum tubes immediately before administration of the next dose of cibenzoline and centrifuged to separate serum. Samples of $1 \mathrm{ml}$ serum were mixed with $1 \mathrm{ml} 0.1 \mathrm{~mol} / \mathrm{L}$ sodium hydroxide, internal standard (4-methylmexiletine: Nippon Boehringer Ingelheim), and $5 \mathrm{ml}$ diethyl ether. After $5 \mathrm{~min}$ of centrifugation at $3,000 \mathrm{rpm}(1,000 \mathrm{G})$, the solvent layer was transferred to evaporation tubes and evaporated at $60^{\circ} \mathrm{C}$. Samples were reconstituted with $200 \mu 1$ mobile phase, and $50 \mu 1$ of this solution were injected into an STR ODS-II column (particle size $5 \mu \mathrm{m}, 250 \mathrm{~mm}, 4.6 \mathrm{~mm}$ : Shinwa Chemical Industries, Kyoto, Japan) at $40^{\circ} \mathrm{C}$. The mobile phase, acetonitrile/
$0.044 \mathrm{~mol} / \mathrm{L}$ phosphate buffer solution containing $0.5 \%$ triethylamine ( $\mathrm{pH} 2.6)$ (1:3 by volume), was pumped at $1.2 \mathrm{ml} / \mathrm{min}$ with detection at $210 \mathrm{~nm}$. Standard curves were linear for cibenzoline over the concentration range of 25$2,000 \mathrm{ng} / \mathrm{ml}$. The between-day and within-day coefficients of variation for the control values were $<5 \%$. Serum concentration/(dose/weight) (C/D) values were calculated for each individual sample.

Blood samples for BNP assay were immediately collected in a chilled glass tube containing disodium EDTA $(1 \mathrm{mg} / \mathrm{ml})$ and aprotinin $(500 \mathrm{U} / \mathrm{ml})$ and centrifuged immediately at $4^{\circ} \mathrm{C}$. Plasma BNP values were measured directly with highly sensitive and specific immunoradiometric assay kits (Shionogi Co Ltd) 20

\section{Statistical Analysis}

Demographic parameters for the study patients were analyzed using Student's t-test. Differences in C/D values between the patients with and without heart failure were analyzed using analysis of covariance (ANCOVA) with Ccr serving as the covariate. Correlation analysis was performed with Pearson's method to estimate the evaluation of predictors on change in $\mathrm{C} / \mathrm{D}$ values of cibenzoline to $\mathrm{Ccr}$. Effects of dose/weight, Ccr and the log-transformed BNP (log-BNP) values on serum cibenzoline concentrations were assessed using an ANCOVA model. In this analysis, the dependent variable was the serum cibenzoline concen- 
tration, and the covariates were dose/weight, $\mathrm{Ccr}$ and the $\log$-BNP value. The BNP value is known to be a useful index for the diagnosis of diastolic dysfunction. However, because the BNP distribution was positively skewed, we used the log-BNP value which was assessed at Gaussian distribution. All statistical analyses were performed with SPSS software (Chicago, IL, USA). Data are expressed as the mean \pm SD. Probability values $\leq 0.05$ were considered statistically significant.

\section{Results}

There were 135 and 361 measurements of serum cibenzoline concentration in 89 patients with heart failure and 279 patients without heart failure. Significant differences were observed in dose/weight, dosage/day, serum cibenzoline concentration, C/D, AST, BUN, Scr, and Ccr, but not in age, weight, height or ALT between the patients with and without heart failure. Pearson's correlation coefficient analyses in the patients with and without heart failure revealed that the $\mathrm{C} / \mathrm{D}$ values were significantly correlated with Ccr (with heart failure, $y=-0.837 x+169, r=-0.211$, $\mathrm{p}=0.014$, without heart failure, $\mathrm{y}=-0.789 \mathrm{x}+132, \mathrm{r}=-0.393$, $\mathrm{p}<0.001)$. The ANCOVA model showed that $\mathrm{C} / \mathrm{D}$ values in the patients with heart failure were significantly higher than those in the patients without heart failure (Fig 1).

Fig 1 shows that the higher C/D values appear to cluster to some degree with heart failure subjects. In order to further evaluate this finding, an ANCOVA was performed that included dose/weight, Ccr, and the log-BNP value. The results of the ANCOVA showed that dose/weight, $\mathrm{Ccr}$ and the log-BNP value were significant factors (Table 3 ).

\section{Discussion}

The present study demonstrated that there was a negative correlation between the cibenzoline $\mathrm{C} / \mathrm{D}$ values and $\mathrm{Ccr}$ in patients with and without heart failure. The renal excretion of cibenzoline is reduced in patients with impaired renal function, because approximately $60 \%$ of the cibenzoline dose is excreted in urine as the parent drug! 10,11 Renal function may be an important factor in the dosage decision for patients treated with cibenzoline. In addition, the present study demonstrated that the $\mathrm{C} / \mathrm{D}$ values of cibenzoline in patients with heart failure were significantly higher than those in patients without heart failure. Because a significant difference was observed in Ccr between the patients with and without heart failure, the C/D values should be evaluated with $\mathrm{Ccr}$ in mind. The ANCOVA model including Ccr was employed for this purpose, which showed that there was a significant difference in the regression lines that related the $\mathrm{C} / \mathrm{D}$ values to $\mathrm{Ccr}$ between the patients with and without heart failure. This observation conflicts with a previous report that there was no difference in the pharmacokinetics of cibenzoline between patients with moderate chronic congestive heart failure and healthy subjects $!^{7}$ However, that report was based on a small number of cases and did not include patients in advanced stages of heart failure. The results obtained from our study suggest that factors other than renal function influence the pharmacokinetics of cibenzoline in patients with heart failure.

As shown in Table 2, there were 81 patients with BNP measurements in the present study. We assessed the effect of dose/weight, Ccr and the log-BNP value on serum cibenzoline concentrations using an ANCOVA model. Our study suggested that the log-BNP value was a useful index for predicting the serum concentration of cibenzoline. It was reported that BNP values could be a useful index for the diagnosis of diastolic dysfunction and the log-BNP value was related to left ventricular ejection fraction. ${ }^{20-24}$ When left ventricular function was evaluated with diastolic function and left ventricular ejection fraction, it was related to BNP25 It is well known that a decrease in renal and hepatic blood flow occurs as a secondary phenomenon in patients with reduced left ventricular function in heart failure ${ }^{26-30}$ and this has a great impact on drug clearance. Therefore, patients with severe heart failure have the potential to decrease total body clearance, including hepatic clearance as well as renal clearance 31,32 This may account for the higher-than-expected serum concentrations of cibenzoline in patients with heart failure compared with patients without heart failure. Consequently, the log-BNP value relating to cardiac function is a useful index for predicting the serum concentration of cibenzoline.

There were some patients with remarkably high serum cibenzoline concentrations in the group with higher BNP values. Cibenzoline administeration was discontinued because of severe depression of left ventricular function in 2 patients who showed serum cibenzoline concentrations greater than $1,000 \mathrm{ng} / \mathrm{ml}$. They had NYHA functional class III severe heart failure on admitting diagnosis with higher BNP values $(1,066.7,285.6)$. The selection of cibenzoline dose based only on renal function seems to have a risk of toxicity in patients with high BNP values, namely severe heart-failure patients, therefore, careful administration of cibenzoline is required for patients with a low left ventricular ejection fraction 33

A precise nomogram has been developed for cibenzoline therapy in Japanese patients with impaired renal function, 34 but a further nomogram should be developed based on a pharmacokinetic and pharmacodynamic study for appropriate dosing of cibenzoline in patients with heart failure, because cibenzoline therapy is not the first selected regimen in patients with heart failure because of the large possibility of cardiac depression.

In conclusion, the selected cibenzoline dose should take into account not only renal function, but also cardiac function. In this regard, the log-BNP may be a useful index for predicting serum cibenzoline concentrations. In addition, therapeutic drug monitoring of cibenzoline should be done to obtain the desired clinical effect and reduce toxic drug reactions in patients with heart failure.

\section{Acknowledgment}

This study was supported by the program for promotion of Fundamental Studies in Health Sciences of the Pharmaceuticals and Medical Devices Agency (PMDA).

\section{References}

1. Arpino PA, Hallisey RK. Effect of renal function on the pharmacodynamics of argatroban. Ann Pharmacother 2004; 38: 25-29.

2. Matzke GR, McGory RW, Halstenson CE, Keane WF. Pharmacokinetics of vancomycin in patients with various degrees of renal function. Antimicrob Agents Chemother 1984; 25: 433-437.

3. Takahashi M, Echizen H, Takahashi K, Shimada S, Aoyama N, Izumi T. Extremely prolonged elimination of cibenzoline at toxic plasma concentrations in patients with renal impairments. Ther Drug Monit 2002; 24: 492-496.

4. Takada M, Goto T, Kotake T, Saito M, Kawato N, Nakai M, et al. Appropriate dosing of antiarrhythmic drugs in Japan requires therapeutic drug monitoring. J Clin Pharm Ther 2005; 30: 5-12.

5. Brazzell RK, Rees MM, Khoo KC, Szuna AJ, Sandor D, Hannigan J. 
Age and cibenzoline disposition. Clin Pharmacol Ther 1984; 36: $613-619$.

6. Massarella JW, Khoo KC, Aogaichi K, Di Persio D, Smith M, Kluger J, et al. Effect of renal impairment on the pharmacokinetics of cibenzoline. Clin Pharmacol Ther 1988; 43: 317-323.

7. Millar JS, Vaughan Williams EM. Effects on rabbit nodal, atrial, ventricular and Purkinje cell potentials of a new antiarrhythmic drug, cibenzoline, which protects against action potential shortening in hypoxia. Br J Pharmacol 1982; 75: 469-478.

8. Konishi C, Shiraishi J, Muraguchi N, Ohtsuki K, Inoue M, Tatsumi $\mathrm{T}$, et al. Beneficial effect of cibenzoline on left ventricular pressure gradient with sigmoid septum. Circ J 2004; 68: 968-971.

9. Hamada M, Shigematsu Y, Inaba S, Aono J, Ikeda S, Watanabe K, et al. Antiarrhythmic drug cibenzoline attenuates left ventricular pressure gradient and improves transmitral Doppler flow pattern in patients with hypertrophic obstructive cardiomyopathy caused by midventricular obstruction. Circ J 2005; 69: 940-945.

10. Canal M, Flouvat B, Tremblay D, Dufour A. Pharmacokinetics in man of a new antiarrhythmic drug, cibenzoline. Eur J Clin Pharmacol 1983; 24: 509-515

11. Khoo KC, Szuna AJ, Colburn WA, Aogaichi K, Morganroth J, Brazzell RK. Single-dose pharmacokinetics and dose proportionality of oral cibenzoline. J Clin Pharmacol 1984; 24: 283-288.

12. Kostis JB, Davis D, Kluger J, Aogaichi K, Smith M. Cifenline in the short-term treatment of patients with ventricular premature complexes: A double-blind placebo-controlled study. J Cardiovasc Pharmacol 1989; 14: 88-95.

13. Babuty D, D'Hautefeuille B, Scheck F, Mycinsky C, Pruvost P, Peraudeau P. Cibenzoline versus flecainide in the prevention of paroxysmal atrial arrhythmias: A double-blind randomized study. $J$ Clin Pharmacol 1995; 35: 471-477.

14. Ollitrault J, Quilliet L, Scheck F, Lelong B, Richard A, Jarry G, et al. Single infusion of intravenous cibenzoline in the treatment of supraventricular tachyarrhythmias following heart surgery: A double-blind placebo-controlled parallel study. Eur Heart J 1994; 15: 1274 1278.

15. Takada M, Shibakawa M. Efficacy of therapeutic drug monitoring in prevention of hypoglycemia caused by cibenzoline. Eur J Clin Pharmacol 2001; 57: 695-700.

16. Cazes M, Chassaing C, Martinet M, Cloarec A, Provost D, Boucher $\mathrm{M}$, et al. Comparison of anticholinergic effects of cibenzoline, disopyramide, and atropine. J Cardiovasc Pharmacol 1990; 15: $308-316$.

17. Massarella JW, Silvestri T, DeGrazia F, Miwa B, Keefe D. Effect of congestive heart failure on the pharmacokinetics of cibenzoline. $J$ Clin Pharmacol 1987; 27: 187-192.

18. Cockcroft DW, Gault MH. Prediction of creatinine clearance from serum creatinine. Nephron 1976; 16: 31-41.

19. Hackman MR, Lee TL, Brooks MA. Determination of cibenzoline in plasma and urine by high-performance liquid chromatography. $J$ Chromatogr 1983; 273: 347-356.

20. Yasue H, Yoshimura M, Sumida H, Kikuta K, Kugiyama K, Jougasaki M, et al. Localization and mechanism of secretion of $\mathrm{B}$ - type natriuretic peptide in comparison with those of A-type natriuretic peptide in normal subjects and patients with heart failure. Circulation 1994; 90: 195-203.

21. Frazier OH, Rose EA, Macmanus Q, Burton NA, Lefrak EA, Poirier VL, et al. Multicenter clinical evaluation of the HeartMate 1000 IP left ventricular assist device. Ann Thorac Surg 1992; 53: 10801090.

22. Yoshimura M, Yasue H, Okumura K, Ogawa H, Jougasaki M, Mukoyama M, et al. Different secretion patterns of atrial natriuretic peptide and brain natriuretic peptide in patients with congestive heart failure. Circulation 1993; 87: 464-469.

23. Lubien E, DeMaria A, Krishnaswamy P, Clopton P, Koon J, Kazanegra R, et al. Utility of B-natriuretic peptide in detecting diastolic dysfunction: Comparison with Doppler velocity recordings. Circulation 2002; 105: 595-601.

24. Joung BY, Park BE, Kim DS, Hong BK, Kim DY, Cho YH, et al. Btype natriuretic Peptide predicts clinical presentations and ventricular overloading in patients with heart failure. Yonsei Med J 2003; 44: $623-634$.

25. Shiba N, Watanabe J, Shinozaki T, Koseki Y, Sakuma M, Kagaya Y, et al, CHART Investigators. Analysis of chronic heart failure registry in the Tohoku district: Third year follow-up. Circ J 2004; 68: $427-$ 434.

26. Weinfeld MS, Chertow GM, Stevenson LW. Aggravated renal dysfunction during intensive therapy for advanced chronic heart failure. Am Heart J 1999; 138: 285-290.

27. Maxwell AP, Ong HY, Nicholls DP. Influence of progressive renal dysfunction in chronic heart failure. Eur J Heart Fail 2002; 4: 125 130.

28. Ueno K, Tamamura A, Matsumoto K, Komamura K, Kamakura S, Miyatake K, et al. Evaluation of mexiletine clearance in a Japanese population. Ann Pharmacother 2002; 36: 241-245.

29. Munger MA, Chance M, Nair R, Prescott AW, Nara AR, Simonson MS, et al. Evaluation of quinapril on regional blood flow and cardiac function in patients with congestive heart failure. J Clin Pharmacol 1992; 32: 70-76.

30. Baldwin RT, Radovancevic B, Conger JL, Matsuwaka R, Duncan JM, Vaughn WK, et al. Peripheral organ perfusion augmentation during left ventricular failure: A controlled bovine comparison between the intraaortic balloon pump and the Hemopump. Tex Heart Inst $J$ 1993; 20: 275-280.

31. Benowitz NL, Meister W. Pharmacokinetics in patients with cardiac failure. Clin Pharmacokinet 1976; 1: 389-405.

32. Woosley RL, Echt DS, Roden DM. Effects of congestive heart failure on the pharmacokinetics and pharmacodynamics of antiarrhythmic agents. Am J Cardiol 1986; 57: 25-33.

33. Seals AA, Haider R, Leon C, Francis M, Young JB, Roberts R, et al. Antiarrhythmic efficacy and hemodynamic effects of cibenzoline in patients with nonsustained ventricular tachycardia and left ventricular dysfunction. Circulation 1987; 75: 800-808.

34. Tsuchishita Y, Mizokawa N, Takeda K, Itou K, Mashimo K, Kameda $\mathrm{T}$, et al. Establishment and evaluation of a nomogram for initial dosage of cibenzoline. Jpn J Ther Drug Monit 2003; 20: 123-124. 